Won W. Choi MD, Mahesh P. Mehta MD, David J. Murray MD, Martin D. Sokoll MD, Robert B. Forbes MD, Samir D. Gergis MD, Martha Abou-Donia PhD,Jerry Kirchner BA

\title{
Neuromuscular and cardiovascular effects of mivacurium chloride in surgical patients receiving nitrous oxide-narcotic or nitrous oxide- isoflurane anaesthesia
}

\begin{abstract}
The neuromuscular and cardiovascular effects of mivacurium chloride were studied during nitrous oxide-oxygen narcotic (fentanyl) $(n=90)$ and nitrous oxide-oxygen isoflurane (ISO) anaesthesia $(n=45)$. In addition, a separate group $(n=9)$ received succinylcholine during fentanyl anaesthesia to compare its neuromuscuiar effects with mivacurium. Mivacurium was initially administered as a single bolus in doses from 0.03 $\mathrm{mg} \cdot \mathrm{kg}^{-1}$ to $0.25 \mathrm{mg} \cdot \mathrm{kg}^{-1}$ io study the dose-response relationships, as well as the cardiovascular effects of mivacurium. Neuromuscular block (NMB) was measured by recording the twitch response of the adductor pollicis muscle following ulnar nerve stimulation $(0.15 \mathrm{~Hz}, 0.2 \mathrm{~ms}$ supramaximal voltage $)$. The $E D_{95}$ values for mivacurium were estimated to be 0.073 $\mathrm{mg} \cdot \mathrm{kg}^{-1}$ and $0.053 \mathrm{mg} \cdot \mathrm{kg}^{-1}$ in the fentanyl and ISO groups respectively. The duration of block (time from injection to 95 per
\end{abstract}

\section{Key words}

ANAESTHETIC TECHNIQUES: balanced; ANAESTHETICS, INTRAVENOUS: fentanYl; ANAESTHETICS, VOLATILE: isoflurane; NEUROMUSCULAR RELAXANTS: mivacurium, succinylcholine; PHARMACOLOGY: dose-response.

Department of Anesthesia, University of lowa College of Medicine Iowa City, IA 52242 and Burroughs Wellcome Co., Research Triangle Park, NC.

Address Correspondence to: Dr. W.W. Choi.

Supported by a grant from Burroughs Wellcome Co., Research Triangle Park, NC. Presented in part at the Annual Meeting of the American Society of Anesthesiologists, Atlanta, GA, October 1987 . cent recovery) for a dose of $0.05 \mathrm{mg} \cdot \mathrm{kg}^{-1}$ mivacurium was 15.3 $\pm 1.0 \mathrm{~min}$ and $21.5 \pm 1.3 \mathrm{~min}$ for fentanyl and $15 \mathrm{O}$ anaesthesia, respectively. The recovery index (25-75 per cent) between initial bolus dose $(6.1 \pm 0.5 \mathrm{~min})$, repeal bolus doses $(7.6 \pm 0.6 \mathrm{~min})$, mivacurium infusion $(6.7 \pm 0.7 \mathrm{~min})$ and succinylcholine infusion $(6.8 \pm 1.8 \mathrm{~min})$ were not significantly different. There was minimal change in mean arterial pressure (MAP) or heart rate (HR) following bolus doses of mivacurium up to $0.15 \mathrm{mg} \cdot \mathrm{kg}^{-1}$. Bolus administration of $0.20 \mathrm{mg} \cdot \mathrm{kg}^{-1}$ or $0.25 \mathrm{mg} \cdot \mathrm{kg}^{-1}$ of mivacurium decreased MAP from $78.2 \pm 2.5$ to $64.0 \pm 3.2 \mathrm{mmHg}$ (range 12-59 per cent of control) $(P<$ 0.05 ). The same doses when administered slowly over $30 \mathrm{sec}$ produced minimal change in MAP or HR.

Recent development of new muscle relaxants, atracurium, vecuronium, and doxacurium, has met most of the goals outlined by Savarese and Kitz' for the ideal muscle relaxant with an intermediate or long duration of action, but the search continues for a drug with rapid onset and short duration of action. This nondepolarizing drug should be noncumulative and should have a rapid, spontaneous recovery. Succinylcholine is frequently used when rapid onset and short duration of neuromuscular blockade are desired. Its usefulness is limited by a number of side effects mainly related to its depolarizing nature of action. ${ }^{2-4}$ Most of these, with the exception of muscle pains, are infrequent but potentially serious.

Mivacurium is a new non-depolarizing neuromuscular blocking agent that is rapidly hydrolyzed by plasma cholinesterase and is currently under clinical evaluation as a short-acting neuromuscular blocking agent. Previous 
clinical studies in human volunteers and healthy surgical patients indicated that the neuromuscular effects of mivacurium are of short duration and readily reversed with anticholinesterase..$^{5-11}$ The purpose of this study was to evaluate the neuromuscular and cardiovascular effects of a wide range of doses of mivacurium during either nitrous oxide-narcotic anaesthesia or nitrous oxideisoflurane anaesthesia in healthy patients requiring elective surgery. In addition, the neuromuscular blocking properties were compared with those of succinylcholine.

\section{Methods and materials}

One hundred forty-four ASA physical status I or II patients, aged $18-70$ years, weighing $40-110 \mathrm{~kg}$, who required elective surgery, were studied after written informed consent was obtained. The protocol for the study was approved by the University of Iowa Human Research Committee. Patients were excluded from the study if they had a history of (1) malignant hyperthermia; (2) unusual sensitivity to neuromuscular-blocking agents; (3) alcohol or drug abuse; (4) psychiatric, neuromuscular or severe cardiovascular disease, or impaired renal or liver function; (5) asthma; (6) exposure to aminoglycoside antibiotics, quinidine, lidocaine, or trimethaphan within $48 \mathrm{hr}$ of the study; (7) exposure to antihistamines or antidepressants within one week of the study; (8) ECG abnormalities; or (9) child-bearing potential.

Premedication included morphine $(0.05-0.15 \mathrm{mg}$. $\left.\mathrm{kg}^{-1}, \mathrm{IM}\right)$, atropine $\left(0.004-0.008 \mathrm{mg} \cdot \mathrm{kg}^{-1}, \mathrm{IM}\right)$, or diazepam $\left(0.1-0.2 \mathrm{mg} \cdot \mathrm{kg}^{-1}, \mathrm{PO}\right) 30-90 \mathrm{~min}$ before the induction of anaesthesia. In the operating room, five per cent dextrose in lactated Ringer's solution was administered via an intravenous catheter.

A force displacement transducer (Grass FT-10) was used to measure and record the twitch response of the adductor pollicis muscle to ulnar nerve stimulation. The ulnar nerve was stimulated at the wrist using two 25-gauge subcutaneous needles. A Grass stimulator delivered square wave pulses at $0.15 \mathrm{~Hz}, 0.2 \mathrm{msec}$ duration, and supramaximal voltage ( $20 \mathrm{~V}$ above maximum response). The twitch response of the adductor pollicis elicited by ulnar nerve stimulation and heart rate by ECG were recorded continuously on a HewlettPackard four channel recorder. Blood pressure was monitored throughout the study with an automated oscillotonometer for estimated drug doses less than $\mathrm{ED}_{95}$ or an intra-arterial catheter for drug doses estimated to be $\mathrm{ED}_{95}$ or greater. The method for development of the doseresponse relationship and $\mathrm{ED}_{95}$ doses for these patients is described later. In those patients who had direct blood pressure measured, blood pressure was continuously monitored and displayed on the four channel recorder. Heart rate and systolic, diastolic, and mean arterial pressures were recorded every minute beginning two minutes before drug administration and continuing for ten minutes following injection of the drug. Direct arterial pressure measurements were continuously recorded over the same time period.

Mass spectrometry (Perkin Elmer) was used to measure end-tidal $\mathrm{CO}_{2}$ and ventilation was controlled or assisted to maintain end-tidal $\mathrm{PCO}_{2}$ in a range of $35-45 \mathrm{mmHg}$. Temperature was maintained at $36.5 \pm 0.5^{\circ} \mathrm{C}$.

The 144 patients were divided into three groups. In 90 patients (ten subgroups with nine patients each (fentanyl 1-10)) mivacurium was administered as a single bolus dose during nitrous oxide, oxygen and narcotic anaesthesia (fentanyl). Forty-five patients who were divided into five subgroups (ISO 1-5) received mivacurium during nitrous oxide, oxygen and isoflurane anaesthesia (ISO). Nine patients received succinycholine (SCH) during $\mathrm{N}_{2} \mathrm{O}$-narcotic anaesthesia (Table I).

In the fentanyl and $\mathrm{SCH}$ groups anaesthesia was induced with thiopentone (3-4 $\mathrm{mg} \cdot \mathrm{kg}^{-1}$ ) and maintained with 60-70 per cent nitrous oxide in oxygen and fentanyl $\left(2-10 \mu \mathrm{g} \cdot \mathrm{kg}^{-1}\right)$. Supplemental doses of thiopentone and fentanyl were administered to maintain anaesthesia. In the ISO group anaesthesia was maintained with nitrous oxide (60-70 per cent) in oxygen and isoflurane (end tidal concentration maintained for $10 \mathrm{~min}, 0.7$ per cent) analyzed by a mass spectrometer. After establishing a baseline neuromuscular response, 15 minutes after induction of anaesthesia, a predetermined dose of mivacurium was injected rapidly over $2-3 \mathrm{sec}$ into a free flowing intravenous catheter. Tracheal intubation, when indicated, was performed either $10 \mathrm{~min}$ following mivacurium injection or after the termination of collection of all haemodynamic data.

Patients in the first four fentanyl subgroups (fentanyl 1-4) were used to determine a dose-response relationship for mivacurium. Subgroup fentanyl 1 received an initial dose of $0.03 \mathrm{mg} \cdot \mathrm{kg}^{-1}$, a dose anticipated to be equivalent to $\mathrm{ED}_{25}$ from previous data. ${ }^{5}$ The dose administered to fentanyl 2 was based on the response of fentanyl 1 and the assumption that the slope of the dose-response curve would be approximately that seen in Basta's study. ${ }^{5}$ Subsequent doses were based on the responses and slope of the regression of fentanyl 1 and fentanyl 2. The $E D_{95}$ was derived by linear regression analysis of the preceding three fentanyl subgroups.

The doses for subgroup fentanyl 5 was $2.0 \times$ ED $_{95}$, fentanyl 6 and 7 was $2.5 \times \mathrm{ED}_{95}$, and $8,9,10$ received $3 \times \mathrm{ED}_{95}$ as determined from the dose response relations data obtained from subgroups fentanyl 1-4.

In all but one of the subgroups (fentanyl 9) muscle twitch was allowed to recover to 95 per cent of control following the initial dose. Spontaneous recovery from 
TABLE 1 Division of study patients into groups, listing drug doses used, mode of supplementation, and type of recovery

\begin{tabular}{|c|c|c|c|c|c|}
\hline Subgroup & $N$ & $\begin{array}{l}\text { Initial dose } \\
\text { (approx. ED) }\end{array}$ & $\begin{array}{l}\text { Actual dose } \\
\left(\mathrm{mg} \cdot \mathrm{kg}^{-1}\right)\end{array}$ & Maintenance & Recovery \\
\hline \multicolumn{6}{|c|}{ A. Mivacurium (fenanyl) } \\
\hline Fent 1 & 9 & $\mathrm{ED}_{25}$ & 0.03 & bolus & spontaneous \\
\hline Fent 2 & 9 & $\mathrm{ED}_{50}$ & 0.04 & bolus & spontaneous \\
\hline Fent 3 & 9 & $\mathrm{ED}_{75}$ & 0.05 & bolus & spontaneous \\
\hline Fent 4 & 9 & $\mathrm{ED}_{95}$ & 0.08 & infusion & spontaneous \\
\hline Fent 5 & 9 & $2 \times E_{95}$ & 0.15 & bolus & spontaneous \\
\hline Fent 6 & 9 & $2 \times \mathbf{E D}_{95}$ & 0.20 (rapid) & infusion & spontaneous \\
\hline Fent 7 & 9 & $2 \times E_{95}$ & 0.20 (slow) & bolus & $\begin{array}{l}\text { reversal (EN) } \\
\text { spontaneous (ON) }\end{array}$ \\
\hline Fent 8 & 9 & $3 \times \mathrm{ED}_{95}$ & 0.25 (rapid) & infusion & $\begin{array}{l}\text { reversal (EN) } \\
\text { spontaneous (ON) }\end{array}$ \\
\hline Fent 9 & 9 & $3 \times \mathrm{ED}_{95}$ & 0.25 (rapid) & repeated bolus & $\begin{array}{l}\text { reversal (EN) } \\
\text { spontaneous (ON) }\end{array}$ \\
\hline Fent 10 & 9 & $3 \times \mathrm{ED}_{95}$ & 0.25 (slow) & infusion & $\begin{array}{l}\text { reversal (EN) } \\
\text { spontaneous (ON) }\end{array}$ \\
\hline \multicolumn{6}{|c|}{ B. Mivacurium (ISO) } \\
\hline ISO 1 & 9 & $\mathrm{ED}_{25}$ & 0.03 & bolus & spontaneous \\
\hline ISO 2 & 9 & $E D_{s 0}$ & 0.04 & bolus & spontaneous \\
\hline ISO 3 & 9 & $\mathrm{ED}_{79}$ & 0.05 & bolus & spontaneous \\
\hline ISO 4 & 9 & $E D_{95}$ & 0.055 & infusion & $\begin{array}{l}\text { reversal (EN) } \\
\text { spontaneous (ON) }\end{array}$ \\
\hline ISO 5 & 9 & $2.5 \times \mathrm{ED}_{9 \mathrm{~s}}$ & 0.010 & infusion & $\begin{array}{l}\text { reversal (EN) } \\
\text { spontaneous (ON) }\end{array}$ \\
\hline \multicolumn{6}{|c|}{ C. Succinylcholine (fentonyl). } \\
\hline C & 9 & $3.0 \times \mathrm{ED}_{90}$ & 1.0 & infusion & spontaneous \\
\hline
\end{tabular}

Fent: nitrous oxide-oxygen-fentanyl.

ISO: nitrous oxide-oxygen-isoflurane.

EN: Even numbers.

ON: Odd numbers.

NMB was evaluated as time from injection to 5,25 and 95 per cent of control twitch height. Recovery index is the time required for recovery to proceed from 25 to 75 per cent of the control value.

To assess ease of using a continuous infusion, patients in fentanyl 4, fentanyl 6, fentanyl 8 and fentanyl 10 received a second bolus dose, $0.1 \mathrm{mg} \cdot \mathrm{kg}^{-1}$, to produce complete neuromuscular block and when the neuromuscular block recovered to approximately five per cent of control response, a continuous infusion was initiated and adjusted to maintain neuromuscular blockade within $95 \pm$ 4 per cent for the duration of the surgical procedure. The initial infusion rate of mivacurium was $10 \mu \mathrm{g} \cdot \mathrm{kg}^{-1}$. $\min ^{-1}$.

Cumulative properties of mivacurium were evaluated in patients in fentanyl 9. After recovery of the twitch response to 95 per cent of control following the initial dose, $0.25 \mathrm{mg} \cdot \mathrm{kg}^{-1}$, a second dose was administered to produce complete neuromuscular block. A minimum of four fixed doses of mivacurium, $0.1 \mathrm{mg} \cdot \mathrm{kg}^{-1}$, were administered sequentially at $5-10$ per cent twitch re- sponse recovery in each patient. Onset, magnitude, and duration of the block that occurred following each supplemental dose were evaluated.

Pharmacological reversal of mivacurium was studied in 11 patients. In these patients spontaneous recovery was observed to ten per cent of control twitch response at which time pharmacological reversal of neuromuscular block was accomplished with atropine $0.015 \mathrm{mg} \cdot \mathrm{kg}^{-1}$ and neostigmine $0.03 \mathrm{mg} \cdot \mathrm{kg}^{-1}$. The times required for $>$ 95 per cent recovery of twitch response and train-of-four ratio $\geq 0.75$ were recorded and compared with spontaneous recovery.

The cardiovascular effects of rapid large bolus doses, 2.5 and $3 \times \mathrm{ED}_{95}$, of mivacurium were evaluated in fentanyl 6-10. In fentanyl $6,8,9$ mivacurium was injected as a rapid bolus over $2-3 \mathrm{sec}$, while in fentanyl 7 and fentanyl 10 the same dose was injected over a $30-\mathrm{sec}$ period.

The influence of isoflurane anaesthesia on neuromuscular blockade was studied in 45 patients who were anaesthetized with $60-70$ per cent $\mathrm{N}_{2} \mathrm{O}$ and 0.7 per cent 
TABLE II Neuromuscular block and recovery data following mivacurium administration during isoflurane or fentanyl anaesthesia

\begin{tabular}{|c|c|c|c|c|c|c|c|c|}
\hline \multirow{2}{*}{$\begin{array}{l}\text { Anaesthesia } \\
\text { group }\end{array}$} & \multirow{2}{*}{$\begin{array}{l}\text { Mivacurium } \\
\text { dose }\left(\mathrm{mg}^{\prime} \mathrm{kg}^{-1}\right) \\
\text { approximate ED }\end{array}$} & \multirow[b]{2}{*}{$N$} & \multirow{2}{*}{$\begin{array}{l}\text { Maximum } \\
\text { block } \\
\text { (\%) }\end{array}$} & \multirow{2}{*}{$\begin{array}{l}\text { Onset to } \\
\text { max. block } \\
\text { (min) }\end{array}$} & \multicolumn{3}{|c|}{$\begin{array}{l}\text { Time to selected levels of spontaneous } \\
\text { recovery }(\mathrm{min})\end{array}$} & \multirow{2}{*}{$\begin{array}{l}R I \\
25 \%-75 \%\end{array}$} \\
\hline & & & & & $5 \%$ & $25 \%$ & $95 \%$ & \\
\hline \multirow[t]{3}{*}{ Narcotic } & $0.03\left(E D_{25}\right)$ & 9 & $37.7 \pm 8.8$ & $5.6 \pm 0.8(8)$ & - & - & $14.3 \pm 2.1(6)$ & \\
\hline & $0.05\left(E D_{75}\right)$ & 9 & $67.8 \pm 6.4$ & $5.6 \pm 0.3$ & $7.0(1)$ & $10.0 \pm 1.0(2)$ & $15.3 \pm 1.0$ & $5.5 \pm 1.5(2)$ \\
\hline & $0.15\left(2 \times \mathrm{ED}_{95}\right)$ & 9 & $99.6 \pm 0.3$ & $3.3 \pm 0.3$ & $12.3 \pm 0.7$ & $15.5 \pm 1.0$ & $24.1 \pm 1.5$ & $5.4 \pm 0.4$ \\
\hline \multirow[t]{3}{*}{ Isoflurane } & $0.03\left(\mathrm{ED}_{25}\right)$ & 9 & $27.4 \pm 8.9$ & $6.4 \pm 0.5$ & - & $12.2(1)$ & $15.1 \pm 2.1(7)$ & $7.3(1)$ \\
\hline & $0.05\left(E D_{90}\right)$ & 9 & $89.1 \pm 2.7$ & $5.5 \pm 0.6$ & $9.8 \pm 0.2$ & $11.4 \pm 0.5(8)$ & $21.5 \pm 1.3^{*}$ & $6.7 \pm 0.6(8)$ \\
\hline & $0.10\left(2 \times E_{95}\right)$ & 9 & $99.7 \pm 0.2$ & $4.0 \pm 0.4$ & 一 & $16.3 \pm 1.7$ & $23.9 \pm 1.6(8)$ & $6.0 \pm 0.8$ \\
\hline
\end{tabular}

Values shown are mean \pm standard error. Number in parenthesis in $n$ when different from the group.

$* P \leq 0.05$ vs fentanyl anaesthesia for identical doses, andior doses that are comparable multiples of the ED95.

isoflurane. Three of the five groups, ISO 1-3, were used to establish a dose-response relationship. Groups ISO 4 and ISO 5 received doses of $1.0 \times \mathrm{ED}_{95}$, and $2 \times \mathrm{ED}_{95}$. The initial dose, $0.03 \mathrm{mg} \cdot \mathrm{kg}^{-1}$, was derived from our data with fentanyl anaesthesia. The second dose was based on the response of the first dose assuming that slopes of the dose-response curves under isoflurane and narcotic anaesthesia were similar. Remaining doses were derived from the response to the first two doses as described for patients in the fentanyl group.

Comparisons with succinylcholine chloride were made in a group of nine patients that received $1.0 \mathrm{mg} \cdot \mathrm{kg}^{-1}$ of succinylcholine as a bolus IV during $\mathrm{N}_{2} \mathrm{O} / \mathrm{O}_{2}$ fentanyl anaesthesia. Following the initial dose of succinylcholine, the muscle twitch response was allowed to recover to approximately five to ten per cent of baseline value, at which time a continuous IV infusion of succinylcholine, $60-120 \mu \mathrm{g} \cdot \mathrm{kg}^{-1} \cdot \min$, was begun to maintain $95 \pm 4$ per cent twitch suppression throughout the surgical procedure.

The magnitude of block, time to achieve maximum block, and time for twitch recovery to 25,75 , and 95 per cent of control, as well as time for train-of-four ratio (applied when twitch tension reached 95 per cent recovery) $\geq 0.75$ were recorded. In all patients the magnitude of block and initial recovery were expressed as per cent of the twitch tension before drug administration (precontrol). This value was also used to determine the percentage of block at which supplemental doses or drug infusions were administered. When final recovery twitch tension, at which train-of-four ratio was greater than 0.75 , was less than 95 per cent of the initial control, the final value (post control) was used for calculating recovery index and other recovery values.

Blood samples for plasma histamine concentration were obtained immediately before and at two and five minutes following mivacurium administration in subgroups fentanyl 6-10. They were analyzed according to a refinement of the radioenzymatic method ${ }^{11}$ originally described by Moss et al. ${ }^{22}$ An additional blood sample was obtained in each patient for determination of plasma cholinesterase activity and dibucaine number. The correlations between the duration of action of various doses of mivacurium and the plasma cholinesterase activity and dibucaine number were studied in 54 patients, who recovered spontaneously to 95 per cent of control.

In the recovery room patients were evaluated at $30 \mathrm{~min}$ intervals until discharge to evaluate the continued adequacy of muscle strength as determined by adequate hand grip and ability to sustain head lift for five seconds.

Dose-response relationships were developed using the probit log dose method of Litchfield and Wilcoxon. ${ }^{12}$ Linear regression techniques were used to assess the relationship between the probit transformation of per cent block and the logarithm of dose. The dose-response data for time to maximum block and duration of neuromuscular block were also analyzed using linear regression. For both of these dependent variables, the replicate observations at each dosage were used to test the linearity of the regression relationship. ${ }^{13}$

Time trends for the cardiovascular variables, MAP, HR, were assessed using multivariate analysis of variance ${ }^{14}$ The relationships between duration of block and plasma cholinesterase activity and dibucaine number were assessed using nonparametric (Spearman) correlation coefficients. ${ }^{15} P \leq 0.05$ was considered significant. Values are expressed as mean $\pm S E M$.

\section{Results}

Division of study patients into groups, drug doses used, type of anaesthesia and recovery are shown in Table I. Mivacurium produced a dose-dependent neuromuscular block in patients receiving both nitrous oxide narcotic and nitrous oxide isoflurane anaesthesia. In those patients given fentanyl anaesthesia, $0.080 \mathrm{mg} \cdot \mathrm{kg}^{-1}$ produced 
TABLE III Recovery times following spontaneous or neastigmine facilitated recovery in patients who received single or repeated maintenance doses or continuous infusion of mivacurium during fentanyl anaesthesia

\begin{tabular}{|c|c|c|c|c|}
\hline & $N$ & $\begin{array}{l}\text { Recovery } \\
\text { at reversal } \\
(\%)\end{array}$ & $\begin{array}{l}\text { Time from injection } \\
\text { of mivacurium to } \\
95 \% \text { recovery } \\
\text { (min) }\end{array}$ & $\begin{array}{l}\text { Recovery index } \\
25-75 \% \\
\text { (min) }\end{array}$ \\
\hline \multicolumn{5}{|l|}{ Spontaneous } \\
\hline Single bolus dose & 15 & - & $28.3 \pm 1.6$ & $6.1 \pm 0.5$ \\
\hline Repeated $(4 x)$ bolus dose & 4 & - & $31.4 \pm 3.4$ & $7.6 \pm 0.6$ \\
\hline \multirow[t]{2}{*}{ Continuous infusion } & 7 & - & $17.1 \pm 2.1$ & $6.7 \pm 0.7$ \\
\hline & & & $\begin{array}{l}\text { Time from injection } \\
\text { of neostigmine to } \\
95 \% \text { recovery }\end{array}$ & \\
\hline \multicolumn{5}{|l|}{ Reversed } \\
\hline Repeated $(4 \times)$ bolus dose & 4 & $37.5 \pm 4.4$ & $5.6 \pm 1.5$ & - \\
\hline Continuous infusion & 7 & $27.0 \pm 5.7$ & $5.3 \pm 0.6$ & - \\
\hline
\end{tabular}

Values shown are mean \pm SEM.

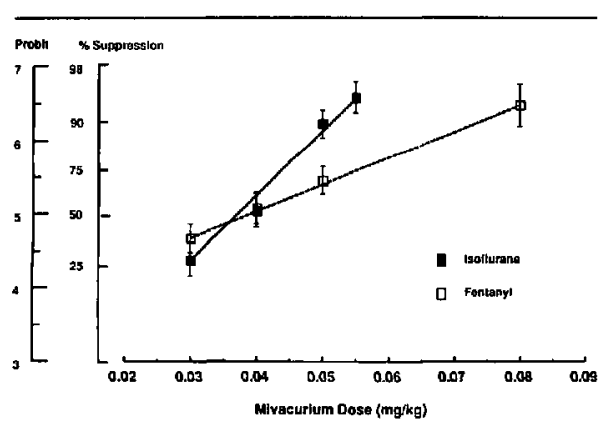

FIGURE \ Dose-response relationship for mivacurium administered during (fentanyl) or (ISO) anaesthesia. Results expressed as Mean \pm SEM.

neuromuscular block of $93.4 \pm 3.3$ per cent. Under ISO anaesthesia, a dose of $0.055 \mathrm{mg} \cdot \mathrm{kg}^{-1}$ produced block of $94.4 \pm 2.2$ per cent. When the data were plotted as a log-probit relationship, calculated $\mathrm{ED}_{50}$ and $\mathrm{ED}_{95}$ were $0.039 \mathrm{mg} \cdot \mathrm{kg}^{-1}$ and $0.073 \mathrm{mg} \cdot \mathrm{kg}^{-1}$ with nitrous-narcotic anaesthesia and $0.037 \mathrm{mg} \cdot \mathrm{kg}^{-1}$ and $0.053 \mathrm{mg} \cdot \mathrm{kg}^{-1}$ with nitrous-isoflurane anaesthesia (Figure 1). There was a dose-related decrease in time to onset of maximum block with both anaesthetic techniques (Figure 2). The time to onset of maximum block for $1.0 \mathrm{mg} \cdot \mathrm{kg}^{-1}$ of succinylcholine was $0.9 \pm 0.1 \mathrm{~min}$ during fentanyl anaesthesia.

Duration of block (time from injection to 95 per cent recovery) for a dose of $0.05 \mathrm{mg} \cdot \mathrm{kg}^{-1}$ was $15.3 \pm 1.0 \mathrm{~min}$ with fentanyl anaesthesia and $21.5 \pm 1.3 \mathrm{~min}$ with ISO anaesthesia. $(P<0.05)$ (Table II) Duration of NMB

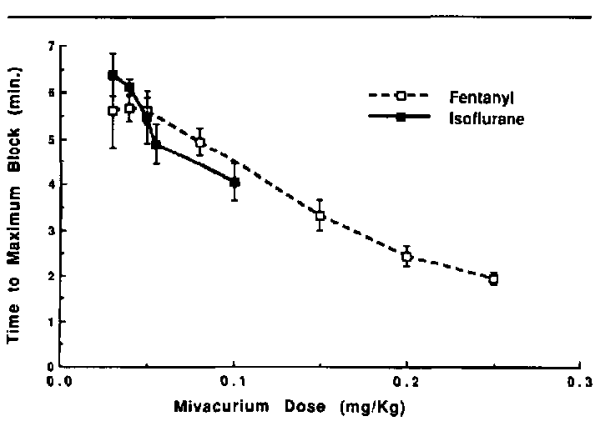

FIGURE 2 Onset time for maximum block with increasing dose of mivacurium during (fentanyl) or (ISO) anaesthesia. Results expressed as Mean \pm SEM.

produced by mivacurium was dose-related with both types of anaesthesia (Figure 3). Train-of-four ratio reached 0.75 or greater within $2.55 \pm 0.92 \mathrm{~min}$ (fentanyl) and $2.36 \pm$ $1.42 \mathrm{~min}$ (ISO) after twitch response had returned to 95 per cent of control twitch response following bolus doses.

The cumulative effects of mivacurium with either repeated bolus doses or continuous infusion were investigated under fentanyl anaesthesia. An initial dose of 0.25 $\mathrm{mg} \cdot \mathrm{kg}^{-1}$ had a recovery index, 25 to 75 per cent recovery, of $6.1 \pm 0.5 \mathrm{~min}$. In the patients who received the same initial dose and were subsequently administered four-to-nine consecutive doses of $0.1 \mathrm{mg} \cdot \mathrm{kg}^{-1}$ at five to ten per cent recovery produced complete block with each drug administration. The mean recovery index following the last dose was $7.6 \pm 0.6 \mathrm{~min}$. Following an initial dose 


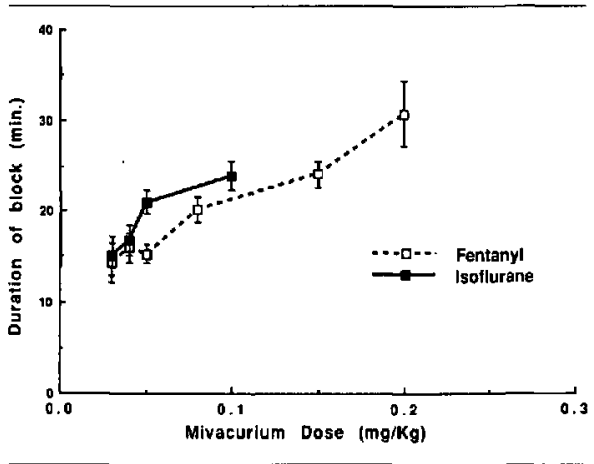

FIGURE 3 Duration of block (time from injection to $95 \%$ recovery) for mivacurium during (fentanyl) or (ISO) anaesthesia. Results expressed as Mean \pm SEM.

of $0.25 \mathrm{mg} \cdot \mathrm{kg}^{-1}$, a continuous infusion to maintain a 95 \pm 4.0 per cent block had a mean recovery index of $6.7 \pm$ $0.7 \mathrm{~min}$ (Table III). There was no significant difference in $\mathrm{Rl}$ among the first and last doses in repeated bolus administration or continuous infusion of mivacurium. Following the initial bolus dose of succinylcholine, $1.0 \mathrm{mg}$. $\mathrm{kg}^{-1}$, a continuous infusion of succinylcholine was adjusted to maintain twitch response at five to ten per cent of control. At the end of continuous succinylcholine infusion, the recovery index was $6.81 \pm 1.8 \mathrm{~min}$ (Table IV).

Reversal of mivacurium induced neuromuscular block was accomplished with atropine $0.015 \mathrm{mg} \cdot \mathrm{kg}^{-1}$ and neostigmine $0.03 \mathrm{mg} \cdot \mathrm{kg}^{-1}$, following single and repeated bolus and continuous infusion (Table III).

Fifteen patients had a low plasma cholinesterase activity (less than $2.3 \mu \mathrm{m} \cdot \mathrm{ml}^{-1} \cdot \mathrm{min}^{-1}$ ) and one patient had a low dibucaine number (Figure 4 A,B). There was no significant correlation between the duration of action
TABLE $\vee$ Histamine levels before and after 0.2 or $0.25 \mathrm{mg} \cdot \mathrm{kg}^{-1}$ of mivacurium bolus administration

\begin{tabular}{llll}
\hline $\begin{array}{l}\text { Dose } \\
m g \cdot g^{-1}\end{array}$ & Baseline & $2 \min$ & $5 \mathrm{~min}$ \\
\hline 0.20 & $313.8 \pm 75.0$ & $3018.3 \pm 17650.9^{*}$ & $1247.0 \pm 351.3^{*}$ \\
0.25 & $469.1 \pm 90.5$ & $14434.7 \pm 8089.7^{*}$ & $3433.7 \pm 1951.4^{*}$ \\
\hline
\end{tabular}

Values are expressed as mean \pm SEM.

${ }^{*} P<0.05$ vs baseline.

of mivacurium and the plasma cholinesterase activity of patients studied(Figure 4A, B).

There was no clinically significant change in mean arterial pressure or heart rate following bolus doses of mivacurium up to and including $0.15 \mathrm{mg} \cdot \mathrm{kg}^{-1}$ in any anaesthetic group (Fig $5 \mathrm{~A}, \mathrm{~B}, \mathrm{C}, \mathrm{D}$ ). Bolus administration of mivacurium, 0.20 or $0.25 \mathrm{mg} \cdot \mathrm{kg}^{-1}$, produced significant decreases in MAP from $78.2 \pm 2.5$ to $64.0 \pm 3.2$ $\mathrm{mmHg}$ (range 12-59 per cent of control) in 52 per cent or 14 out of 27 patients within two minutes. This change was of short duration and within five minutes MAP was within ten per cent of control in all but one patient (fentanyl/ pt. \#69). This patient required treatment for haemodynamic instability (ephedrine $10 \mathrm{mg}$, IV). Four patients in the $0.20 \mathrm{mg} \cdot \mathrm{kg}^{-1}$, fentanyl 6 , and six patients in the 0.25 $\mathrm{mg} \cdot \mathrm{kg}^{-1}$, fentanyl 8 , groups had a cutaneous flush following rapid administration of mivacurium and corresponding increased histamine levels (Table V). The same doses of mivacurium administered slowly over $30 \mathrm{sec}$ produced no clinically significant change in mean arterial pressure. There was no clinically significant change in heart rate at any time in all doses studied.

\section{Discussion}

In this study, a dose-response relationship was established for the neuromuscular actions of mivacurium in humans under either fentanyl or ISO anaesthesia. With this drug, time to onset, magnitude and duration of maximal block

TABLE IV Recovery times following mivacurium or succinylcholine administration by infusion

\begin{tabular}{lrlll}
\hline & & $\frac{25-75 \% \text { recovery index }}{2}$ & $\frac{95 \% \text { recovery time }}{(\mathrm{min})}$ \\
\hline $\begin{array}{l}\text { Mivacurium } \\
\text { Single bolus dose }\end{array}$ & $n$ & 15 & $6.1 \pm 0.5$ & \\
Continuous infusion & 7 & $6.7 \pm 0.7$ & $28.3 \pm 1.6$ \\
Succinycholine & & & $17.1 \pm 1^{*}$ \\
Continuous infusion & 9 & $6.8 \pm 1.8$ & $13.5 \pm 3.1^{*}$ \\
\hline
\end{tabular}

*Time from termination of infusion to $95 \%$ recovery.

Values are mean \pm SEM. 


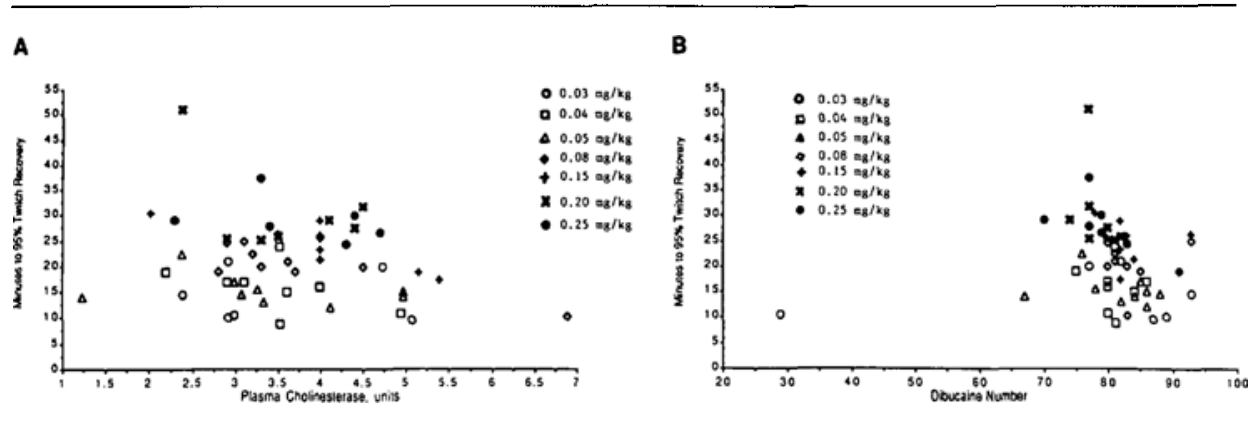

FIGURE 4 Correlation of plasma cholinesterase activity (A) and dibucainc number (B) of individual subjects with duration of block following various doses of mivacurium during fentanyl anaesthesia.

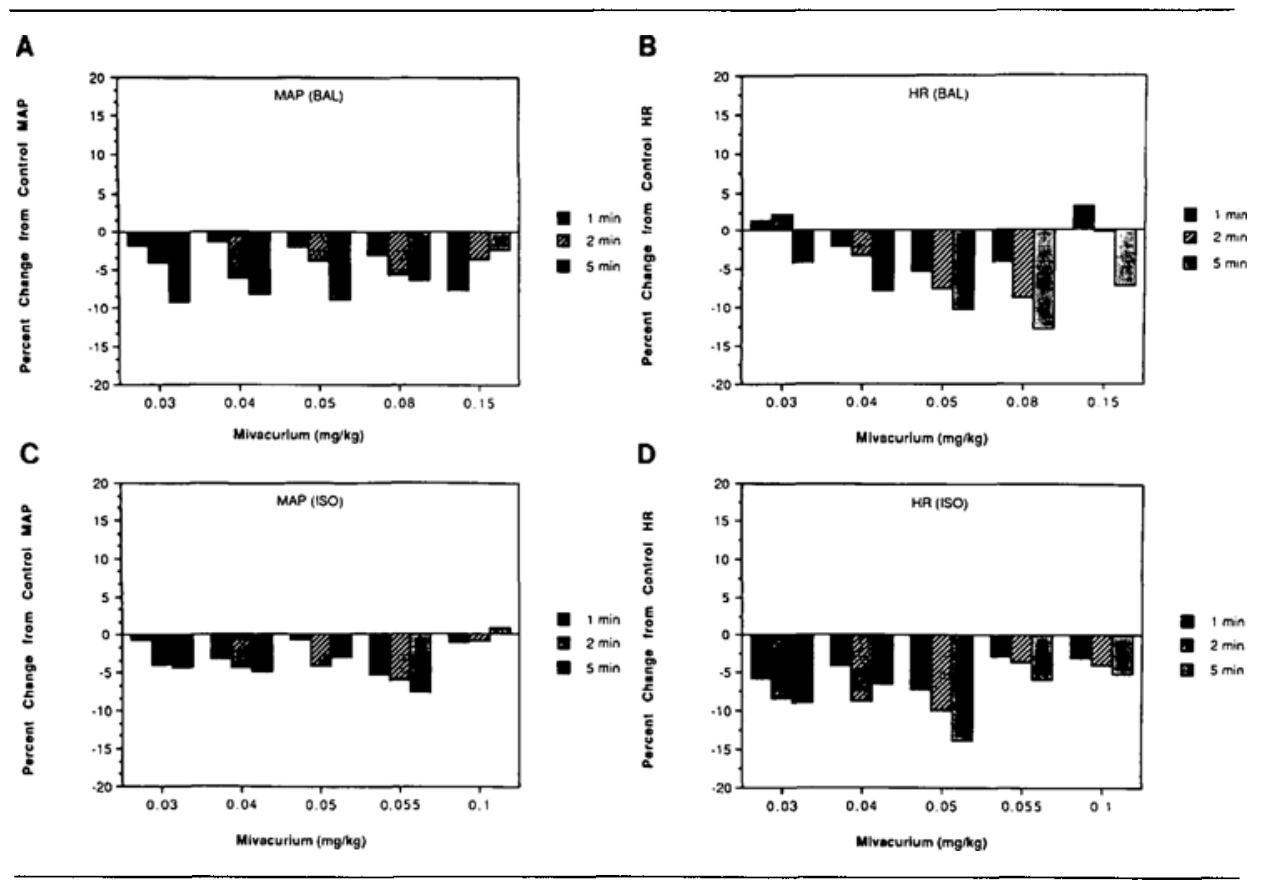

FIGURE 5 Mean arterial pressure and heart rate change (per cent of control) at 1,2 and 5 minutes following various doses of mivacurium during fentanyl anaesthesia ( $A$ and $B$ ) and $1 S O$ anaesthesia (C and D). 
A

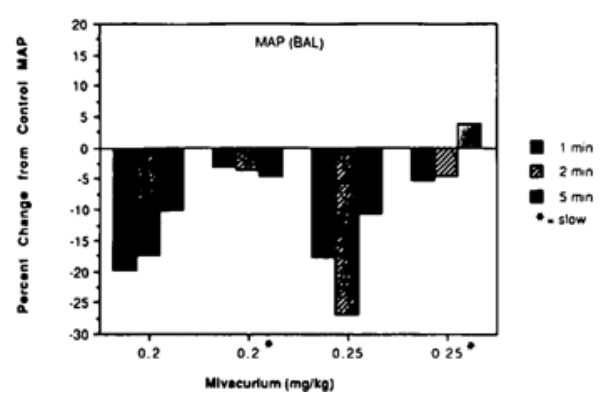

B

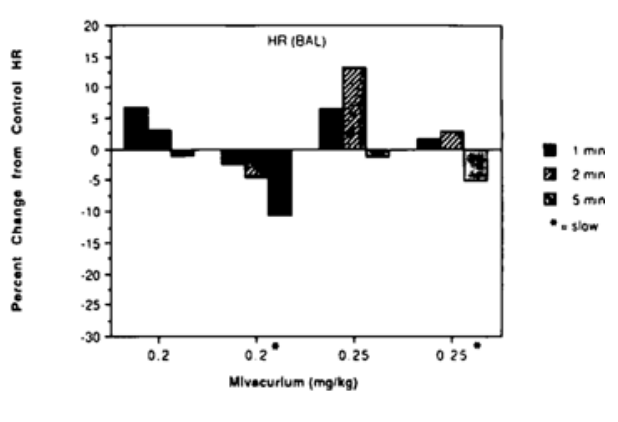

FIGURE 6 Effect of speed of injection on mean arterial pressure and heart rate (per cent of control) at 1,2, and 5 min following rapid bolus (<5 $\mathrm{sec})$ and slow bolus $(30 \mathrm{sec})$ administration of mivacurium $\left(\geq 2.5 \times \mathrm{ED}_{9 \mathrm{9}}\right)$ during fentanyl anaesthesia.

are dose-dependent. The finding in this study of a dose-dependent shortening of the time of development of neuromuscular blockade is in agreement with the work of Savarese ${ }^{6}$ and Weber. ${ }^{7}$ A similar decrease in time of onset of NMB with increasing doses has also been reported by Brown et al. ${ }^{16}$ for pancuronium and Sokoll $e t$ al. ${ }^{17}$ for atracurium.

The influence of ISO anaesthesia on mivacuriuminduced neuromuscular block when compared with fentanyl anaesthesia in this study is different from the work of Weber. ${ }^{7}$ The difference in dose response during isoflurane and fentanyl anaesthesia in this study may suggest a different mechanism of neuromuscular block produced by mivacurium during isoflurane anaesthesia compared with fentanyl anaesthesia. It is, however, more likely to be due to individual variability in response to drug and a small sample size or both. Patients anaesthetized with nitrous oxide-narcotic show a markedly variable response to low-dose neuromuscular blocking agent. ${ }^{18}$ In one patient in the fentanyl group a dose of $0.3 \mathrm{mg} \cdot \mathrm{kg}^{-1}, E_{25}$, produced 80 per cent twitch suppression. The calculated $\mathrm{ED}_{95}$ of mivacurium with ISO and fentanyl anaesthesia was similar to those of other studies. ${ }^{6,7}$

The mean recovery index, defined as the time required for 25 to 75 per cent recovery, following administration of repeated fixed doses of mivacurium ( $7.58 \pm 0.67 \mathrm{~min}$ ) or continuous infusion $(6.66 \pm 0.73 \mathrm{~min})$, was similar to the mean recovery index of the initial dose $(6.10 \pm 0.47)$. We interpret this as suggesting that little or no pharmacodynamic cumulative effect occurs during repeated doses of mivacurium. This may be due to rapid hydrolysis of mivacurium by plasma cholinesterase. ${ }^{6}$
The recovery index following a continuous infusion of mivacurium ( $6.66 \pm 0.73 \mathrm{~min}$ ) is comparable with that following an infusion of succinylcholine $(6.80 \pm 1.80$ min). Our data support that of Ali et al. ${ }^{19}$ who suggested that the recovery index following a mivacurium infusion is more predictable than recovery following succinylcholine, when infusions of similar duration producing similar degrees of neuromuscular block are compared. The variable recovery after a succinylcholine infusion may be related to the drug's potential to produce phase II block. ${ }^{20,21}$

Since spontaneous recovery from mivacurium-induced block was rapid, antagonism of residual mivacuriuminduced block would seem necessary less frequently than following administration of other nondepolarizing agents. Reversal of mivacurium-induced block was accomplished with atropine $0.015 \mathrm{mg} \cdot \mathrm{kg}^{-1}$ and neostigmine 0.03 $\mathrm{mg} \cdot \mathrm{kg}^{-1}$ following a single dose, repeated boluses or continuous infusion.

The poor correlation between plasma cholinesterase activity and duration of action of mivacurium in individual subjects in this study may be attributed to relatively small variance of cholinesterase activity in this group of patients or another route of metabolism and/or excretion of mivacurium. These observations are similar to those of Savarese et al. ${ }^{6}$

The cardiovascular effects (mean arterial blood pressure, heart rate) of mivacurium is minimal with the doses up to approximately $2 \times \mathrm{ED}_{95}$ during either anaesthetic technique. This is supporting evidence that the drug has little autonomic stimulating or blocking effect with low doses. Bolus administration of large doses $(>2.5 \times$ 
$\mathrm{ED}_{95}$ ) of mivacurium produced a significant, but transient, decrease in blood pressure. The same dose of drug, when administered slowly, caused no significant cardiovascular change. If drug-induced histamine release is closely related to the peak plasma level achieved, ${ }^{22}$ then a drug that is rapidly cleared might be expected to release less histamine when administered slowly.

Mivacurium is a neuromuscular blocking agent which has a short duration of action without cumulative effects and minimal cardiovascular change in doses up to $2 x$ $\mathrm{ED}_{95}$. Large bolus doses $\left(>2.5 \times \mathrm{ED}_{95}\right)$ of mivacurium produced a significant decrease in MAP and a corresponding increase in histamine levels.

\section{References}

I Savarese JJ, Kitz RJ. Does clinical anesthesia need new neuromuscular blocking agents? Anesthesiology $1975 ; 42: 236-9$

2 Gronert GA, Dotin LN, Ritchey CR et al. Succinylcholineinduced hyperkalemia in burned patients, Parts I \& II. Anesth Analg, 1969; 48: 764-70, 958-62.

3 Gronert GA, Theye RA. Pathophysiology of hyperkalemia induced by succinylcholine. Anesthesiology 1975; 43: 89-99.

4 Cooperman $L H$. Succinylcholine induced hyperkalemia in neuromuscular disease. JAMA 1970; 213: 1867-71.

5 Basta SJ, Savarese JJ, Ali HH et al. The neuromuscular pharmacology of BW $1090 \mathrm{U}$ in anesthetized patients. Anesthesiology 1985; 63: A318.

6 Savarese JJ, Ali HH, Basta SJ et al. The clinical neuromuscular pharmacology of mivacurium chloride (BW 1090U) Anesthesiology 1988; 68: 723-32.

7 Weber S, Brandom BW. Powers DM et al. Mivacurium (BW 1090U) induced neuromuscular blockade during nitrous oxide-isoflurane and nitrous oxide-narcotic anesthesia in adult surgical patients. Anesth Analg 1988; 67: 495-9.

8 Caldwell JE, Kitts JB. Heine T, Fahey MR, Lynam DP, Miller $R D$. The dose-response relationship of mivacurium chloride in humans during nitrous oxide-fentanyl or nitrous oxide-enflurane anesthesia. Anesthesiology 1989; 70: 31-5.

9 Sarner JB, Brandom BW, Woelfel SK et al. Clinical pharmacology of mivacurium chloride (BW B 1090U) in children during nitrous oxide-halothane and nitrous oxidenarcotic anesthesia. Anesth Analg 1989; 68: 116-21.
10 Goudsouzian NG, Alifimoff $J K$, Eberly $C$ et al. Neuromuscular and cardiovascular effects of mivacurium in children. Anesthesiology 1989; 70: 237-42.

11 Savarese JJ, Ali HH, Basta SJ et al. The cardiovascular effects of mivacurium chloride (BW 1090U) in patients receiving nitrous oxide-opiate barbiturates anesthesia. Anesthesiology 1989, 70: 386-94.

12 Litchfield JT, Wilcoxon JMF. A simplified method of evaluation dose-effect experiments. J Pharmacol Exp Ther 1945; 95: 99-113.

13 Neter J, Wasserman W, Kumer MH. Applied linear regression models. Homewood, IL: Irwin 1983, 123-32.

14 Morrison $D F$. Multivariate Statistical Methods. 2nd ed. NY: McGraw-Hill, 1976, 170-92.

15 Rosner B. Fundamentals of Biostatistics, 2nd Ed. Boston: Busbury 1986, 419-424.

16 Brown EM, Krishnaprasad DK, Smiler BG. Pancuronium for rapid induction technique for tracheal intubation. Can Anaesth Soc J 1979, 26: 489-91.

17 Sokoll MD, Gergis SD, Mehra M, Ali NM, Lineberry C. Safety and efficacy of atracurium (BW33A) in surgical patients receiving fentanyl or isoflurane anesthesia. Anesthesiology 1983; 58: 450-5.

$18 \mathrm{Katz} R D$. Neuromuscular effects of d-tubocurarine, edrophonium and neostigmine in man. Anesthesiology 1967; 28: 327-36.

19 Ali HH, Savarese JJ, Embree PB et al. Clinical pharmacology of BW $1090 \mathrm{U}$ continuous infusion. Anesthesiology 1986; 65: A282.

20 Ramsey FM, Lebowitz PW, Savarese JJ, Ali HH. Clinical characteristics of long term succinylcholine neuromuscular blockade during Fentanyl anaesthesia. Anesth Analg 1980; 59: 110 .

21 Sokoll MD, Bastron RD. The duration of desensitization (phase 2) block after succinylcholine infusion. Anesth Analg 1967; 46: 682-9.

22 Moss J, Rosow CE, Savarese JJ, Philbin DN, Kniffen KJ. Role of histamine in the hypotensive action of d'tubocurarine in humans. Anesthesiology 1981; 55: 19-25. 
Résumé

Les effets cardiovasculaires et neuromusculaires $d u$ chlorure de mivacurium ont été étudiés lors d' une anesthésie au narcotique (fentanyl) protoxyde d'azote-oxygène $(n=90)$ et isoflurane (ISO) protoxyde d'azote-oxygéne ( $n=45)$. En plus, un groupe séparé $(n=9)$ a reçu du succinylcholine lors d' une anesthésie au fentanvl afin de comparer ces effets neuromusculaires avec le mivacurium. Le mivacurium a été initialement administré comme un bolus unique les doses de $0,03 \mathrm{mg} \cdot \mathrm{kg}^{-1}$ et $0,25 \mathrm{mg} \cdot \mathrm{kg}^{-1}$ afin d'ésudier la courbe dose-réponse et les effets cardiovasculaires du mivacurium. Le bloc neuromusculaire (NMB) a été mesuré en enregistrant la réponse au twitch de l'adducteur du pouce après stimulation du nerf cubital $(0.15 \mathrm{~Hz}$, $0.2 \mathrm{~ms}$ voltage supramaximal). Les valeurs de ED95 du mivacurium ont été estimées à $0,073 \mathrm{mg} \cdot \mathrm{kg}^{-1}$ et 0,053 $\mathbf{m g} \cdot \mathbf{k g}^{-l}$ respectivement pour le groupe fentanyl et ISO. La durée du bloc (temps a partir de l'injection à la recouvrance à 95 pour cent) pour une dose de $0,05 \mathrm{mg} \cdot \mathrm{kg}^{-1}$ de mivacurium était de $15,3 \pm 1,0 \mathrm{~min}$. et $21,5 \pm 1,3 \mathrm{~min}$. respectivement pour le groupe fentanyl et le groupe ISO. L'index de recouvrance (25-75 pour cent) entre le bolus initial $(6,1 \pm 0,7 \mathrm{~min})$ la dose de rajout $(7,6 \pm 0,6 \mathrm{~min})$ et la perfusion de mivacurium $(6,7 \pm$ $0,7 \mathrm{~min})$ et la perfusion de succinycholine $(6,8 \pm 1,8 \mathrm{~min})$ n'était pas significativement différent. On a observé des changements minimes dans la pression artérielle moyenne (MAP) ou la fréquence cardiaque (HR) après le bolus de mivacurium jusqu'à $0,15 \mathrm{mg} \cdot \mathrm{kg}^{-1}$. Une administration en bolus de $0,20 \mathrm{mg} \cdot \mathrm{kg}^{-1}$ ou $0,25 \mathrm{mg} \cdot \mathrm{kg}^{-1}$ de mivacurium a diminué la pression artérielle moyenne de $78,2 \pm 2,5$ a 64.01 $3,2 \mathrm{mmHg}$ (écan de $12-59$ pour cent du contróle) $(P<0.05$ ) Les mêmes doses lorsque administrées lentement au-dessus de 30 secondes ont produit des changements minimes de la pression artérielle moyenne et de la fréquence cardiaque. 